\title{
Yield table for selected black locust (Robinia pseudoacacia L.) cultivars
}

\author{
Károly Rédei ${ }^{1}$ - Tamás Ábri ${ }^{1,2}$ - Fruzsina Szabó ${ }^{1}$ - Zsolt Keserü ${ }^{2}$ \\ ${ }^{1}$ Faculty of Agricultural and Food Sciences and Environmental Management, University of Debrecen, Debrecen, Hungary \\ ${ }^{2}$ Forest Research Institute, Department of Plantation Forestry, Püspökladány, Hungary \\ abri.tamas@uni-sopron.hu
}

\begin{abstract}
SUMMARY
In Hungary, the black locust (Robinia pseudoacacia L.) can be considered as the most important fast-growing, stand-forming introduced tree species. Due to its positive growing technological characteristics as well as wood utilization possibilities, at the present, black locust is the most widely planted tree species in Hungary, covering 25\% of the country's total forest area. One of the important tasks ahead of Hungarian black locust growers is to improve the quality of black locust stands with introducing selected cultivars. For the estimation of the growth rate and yield a numerical yield table has been constructed on the basis of surveys of the experimental plots established in pure, managed 'Nyirségi', 'Üllöi' and 'Jászkiséri' black locust cultivars' plantations which can be suitable for sawlogs production. In the course of 56 stand surveys the key stand characteristics were measured, and then, were reconsidered the average height, diameter (DBH), volume, basal area and stem number given separately for the main (remaining), secondary (removal) and total stands per hectare. The programmable editing procedure allows to extention and formal change of information content of the yield table according to different demands.
\end{abstract}

Keywords: Robinia pseudoacacia L.; cultivars; growth; yield

\section{INTRODUCTION}

Nowadays, black locust (Robinia pseudoacacia L.), the tree species native to North-America, is naturalized and widely planted throughout the world from temperate to subtropical areas (Nicolescu et al., 2018). It was the first North-American tree species imported to Europe at the beginning of the $17^{\text {th }}$ century (Demené and Merzeau, 2007).

Since (1710s) its introduction into Hungary black locust has been closely associated with agriculture, and its wood could be utilized for many agricultural and domestic purposes. Recently, black locust has played a role of great importance in the Hungarian forest management, covering approximately $25 \%$ of the forested area. Almost half of the approximately 1.6 million $\mathrm{m}^{3}$ of black locust harvested annually is of industrial wood quality, the rest is only suitable as firewood (Rédei et al., 2017; Nicolescu et al., 2018)

In Hungary, after World War II, significance of black locust changed, because large-scale farms had less demand for wood and the timber industry was not willing to buy black locust wood. It was necessary to improve the quality of final products of black locust. Selection breeding was a good option for it. The main target of the selection breeding was to improve the quality of stem, to increase the output of industrial wood. Besides the varieties recommended for timber production as their primary function, there are others that have been improved for honey production or energy production. New cultivars had to be produced by improvement techniques introducing them into the practical forestry use (Keresztesi, 1988; Rédei et al., 2011; 2017).

Mono- and multiclonal cultivars were developed and a seed orchard was established from the selections.
Some cultivars are suitable for both forestry and honey production. Such double-use cultivars are 'Zalai', 'Kiskunsági', 'Császártöltési', 'Egylevelü', and 'Váti46' (Keresztesi, 1988).

Black locust cultivars that can be suitable for sawlogs production are of decisive importance for primary wood production. Based on this, we selected 'Nyírség', 'Ülloii' and 'Jászkiséri' cultivars for systematic yield studies. Based on the evaluations of long-term yield experimental plots (Bujtás, 1984; Keresztesi, 1988; Rédei, 1984, 1994, 2006, 2008, 2013; Hegede, 2018; Rédei et al., 2020) it has also become possible to compile their yield table, which is the first to be published in English in this publication.

The Hungarian primary wood production practice uses yield tables with 6 yield classes (Sopp and Kolozs, 2000). However, the cultivation technological objectives and economic aspects of plantation forestry are mainly take into account only the stands of I-IV. yield classes. Consequently, our table presented in this paper contains only 5 yield classes.

\section{MATERIALS AND METHODS}

The yield table was constructed from data gathered on 29 forest subcompartments (56 sampling plots), located in different parts of Hungary (Figure 1). The age of the examined stands varied between 5 and 35 years. Their sites are typically forest-steppe and Turkey oak-sessile oak forest climate, free-draining site, humic sand and brown forest soil. The initial stem number of afforestations varied between 3000-5000 stems/ha. In stands up to the age of 10 years, one, and in the case of stands over the age of 18-20 years, two stem number reductions were carried out. 


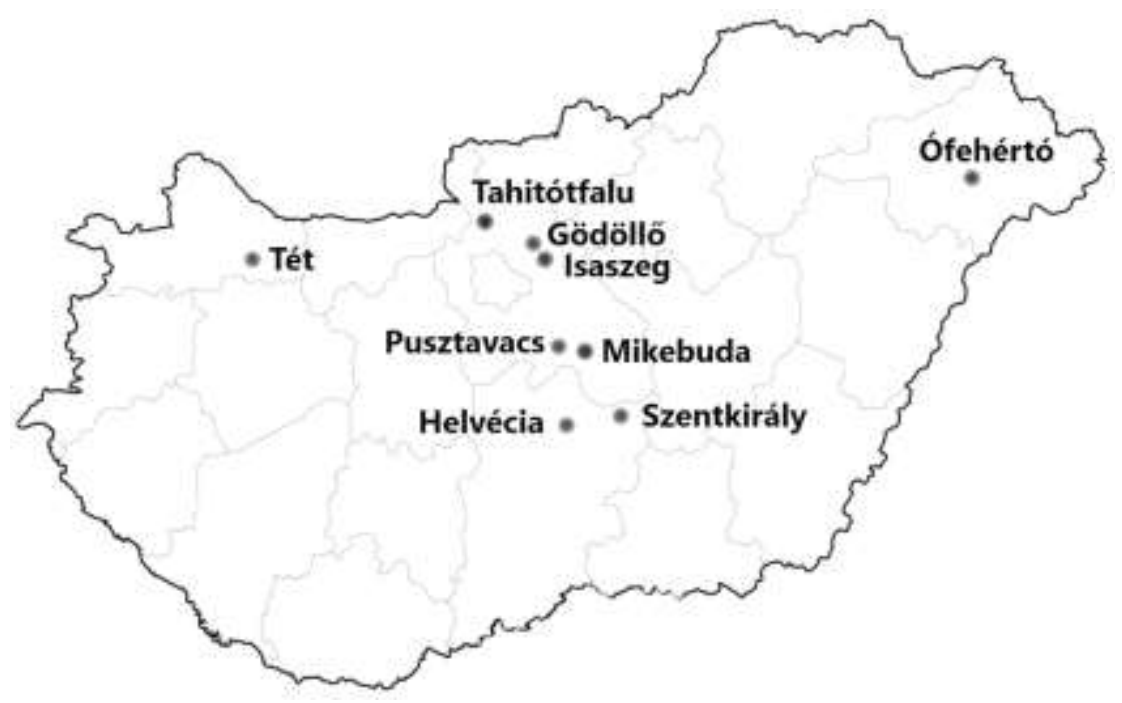

The sampling plots were square shaped, their areas approximately $1000 \mathrm{~m}^{2}$, the boundaries were marked. In the course of the stand surveys the key stand characteristics were measured, and then, on the basis of data collected were calculated the average height, diameter (DBH), volume, basal area and stem number given separately for the main (remaining), secondary (removal) and total stands per hectare (Husch et al.,

$$
v=10^{-8} d^{2} h^{1}(h /[h-1.3])^{2}[-0.6326 d h+20.23 d+0.0 h+3034]
$$

where $v$ is stem volume $\left(\mathrm{m}^{3}\right), d$ is diameter at breast height $(\mathrm{cm})$, and $h$ is tree height $(\mathrm{m})$.

The yield table was constructed using the following formulas and coefficients,

$$
\mathrm{H}_{\mathrm{bam}}=19.4669-57.08546 *[\log (\mathrm{A})]+73.57742 *[\log (\mathrm{A})]^{2}-22.80025 *[\log (\mathrm{A})]^{3}+28.08599 *[\log (\mathrm{A})]^{4}
$$

3. $\mathrm{D}_{\text {bam }}=$ average $\mathrm{DBH}$ of main crop (remaining stand) in $\mathrm{cm}$, where

$$
\mathrm{D}_{\mathrm{bam}}=(0.69880+0.00770 * \mathrm{~A}) * \mathrm{H}_{\mathrm{bam}}
$$

4. $\mathrm{V}_{\mathrm{bm}}=$ volume of main crop (remaining stand) in $\mathrm{m}^{3} \cdot \mathrm{ha}^{-1}$, where

$$
\mathrm{V}_{\mathrm{bm}}=\mathrm{BA}_{\mathrm{m}} * \mathrm{H} * \mathrm{~F}
$$

and $\mathrm{H} * \mathrm{~F}=$ form-height quotient

$$
\mathrm{H} * \mathrm{~F}=1.60430+0.42390 * \mathrm{H}_{\mathrm{bam}}
$$

5. $\mathrm{BA}_{\mathrm{m}}=$ basal area of main crop (remaining stand) in $\mathrm{m}^{2} \cdot \mathrm{ha}^{-1}$,

$$
B A_{m}=\frac{D_{\text {bam }}^{2} * \pi}{4 * 10000} * N_{m}
$$

1. Age of stand (A),

2. $\mathrm{H}_{\mathrm{bam}}=$ average height of main crop (remaining stand) (height of dominant and codominant trees) in $\mathrm{m}$ (base age: 20 year, where $\left.\mathrm{H}_{\mathrm{bam}} \%=100\right)$, where
1982; Avery and Buckhart, 1994; Röhle, 1999; Laar Akca, 2007). We classified each tree according to tree, class 2: subdominant trees, and class 3 : trees to

Stem volume was estimated by the following volume function (Sopp and Kolozs, 2000), 
11. $\mathrm{N}_{\mathrm{r}}=$ stem number of removal stand calculated from reduction of stem number of main crop in five year intervals in $\mathrm{ha}^{-1}$

12. $\mathrm{H}_{\mathrm{t}}=$ average height of total stand in $\mathrm{m}$,

$$
\mathrm{H}_{\mathrm{t}}=-0.09666+0.98613 * \mathrm{H}_{\mathrm{bam}}
$$

13. $\mathrm{D}_{\mathrm{t}}=$ average $\mathrm{DBH}$ of total stand in $\mathrm{cm}$,

$$
D_{t}=\sqrt{\frac{B A_{t} * 10000}{N_{t} * \pi} * 2}
$$

14. $\mathrm{V}_{\mathrm{bt}}=$ volume of total stand in $\mathrm{m}^{3} \mathrm{ha}^{-1}$,

$$
\mathrm{V}_{\mathrm{bt}}=\mathrm{V}_{\mathrm{bm}}+\mathrm{V}_{\mathrm{br}}
$$

15. $\mathrm{BA}_{\mathrm{t}}=$ basal area of total stand in $\mathrm{m}^{2} \cdot \mathrm{ha}^{-1}$,

$$
\mathrm{BA}_{\mathrm{t}}=\mathrm{BA}_{\mathrm{m}}+\mathrm{BA}_{\mathrm{r}}
$$

16. $\mathrm{N}_{\mathrm{t}}=$ stem number of total stand in $\mathrm{ha}^{-1}$,

$$
\mathrm{N}_{\mathrm{t}}=\mathrm{N}_{\mathrm{m}}+\mathrm{N}_{\mathrm{r}}
$$

17. Cumulative volume of intermediate cuttings $=$ total volume of removal stands in $\mathrm{m}^{3} \cdot \mathrm{ha}^{-1}$

18. Share of intermediate cuttings $=$ Total intermediate cutting/ $\mathrm{V}_{\mathrm{bt}} * 100$

19. $\mathrm{V}_{\mathrm{bt}}=$ Total yield

20. Mean annual increment (MAI) of total yield $=V_{b t} / A$ 21. Current increment of total yield $=1$ year increment of total yield

\section{RESULTS AND DISCUSSION}

Yield class is called the intensity of height growth of a given stand compared to the all same tree species of the country, from best to worst from I to V marked by Roman numerals (stands are classified into the yield class I-V). The normative yield table prepared for the above mentioned black locust selected cultivars contains the most important stand structure and yield factors of the main, removal and total stand (height, diameter at breast height, basal area, volume, age and number of stems), divided into five yield classes with the same relative height growth.

When using the yield table for determining the actual volume per ha $\left(\mathrm{V}_{\text {act }}\right)$ of a stand, a basal area ratio is to be recommended:

$$
\mathrm{V}_{\mathrm{act}}=\mathrm{V}_{\mathrm{tab}} \times \mathrm{BA}_{\mathrm{act}} \mathrm{BA}_{\mathrm{tab}}{ }^{-1} \text {, where: }
$$

$\mathrm{V}_{\text {tab }}=$ volume of the stand by yield table according to the age and yield class,

$\mathrm{BA}_{\mathrm{act}}=$ actual basal area of the stand per ha,

$\mathrm{BA}_{\mathrm{tab}}=$ basal area by yield table according to the age and yield class of the stand.

The standard deviation of the average height of the stands from cultivars is shown in Figure 2, and the numerical yield table with five yield classes is shown in Table 1.

Figure 2. Mean height values of examined black locust cultivars in the function (based on data of full inventory)

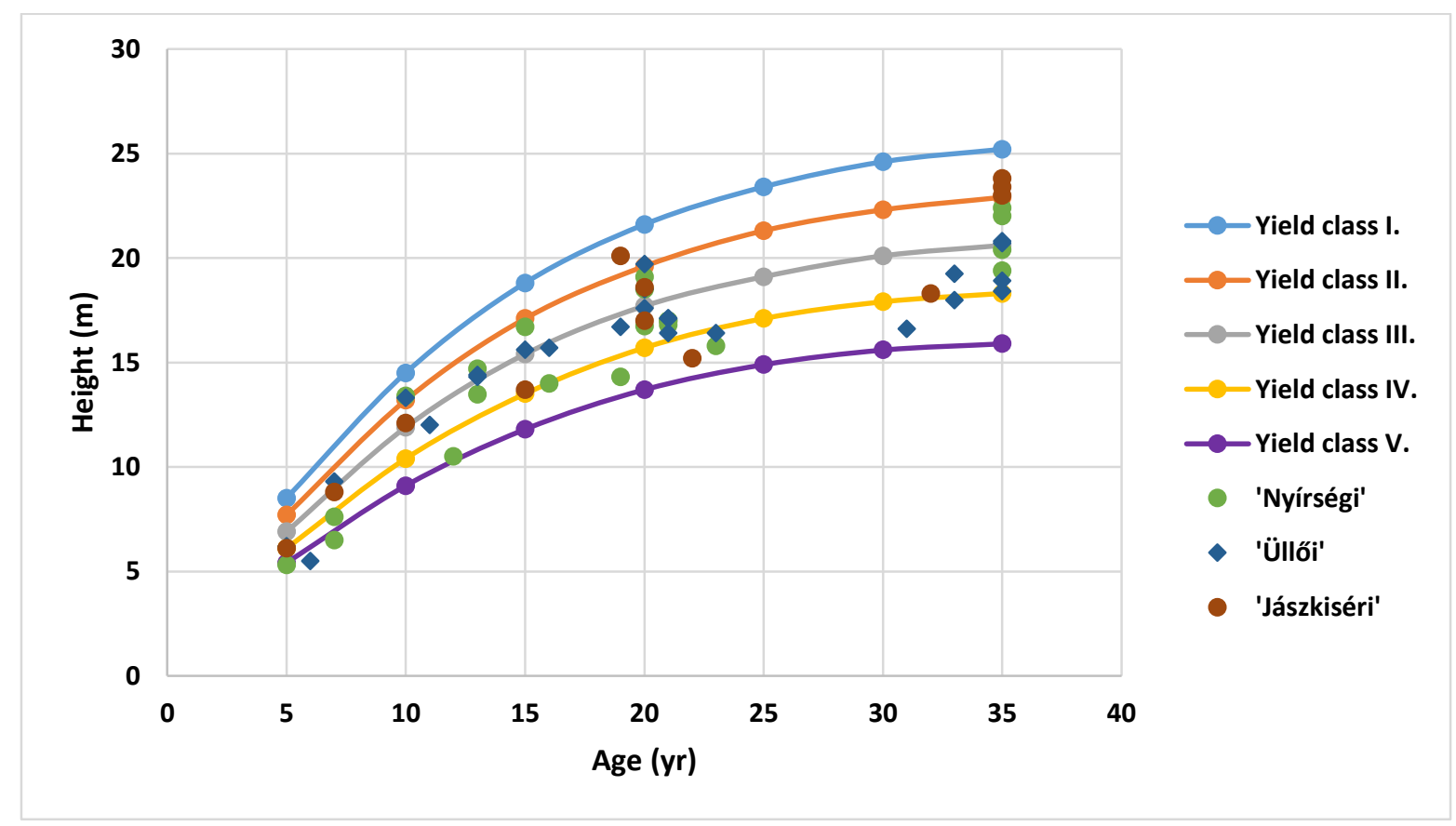

Figure 3. a to 3.e show the height, DBH, and volume indices for main stand as well as the total volume and the mean annual increment of total volume indices in function of age and yield class. 


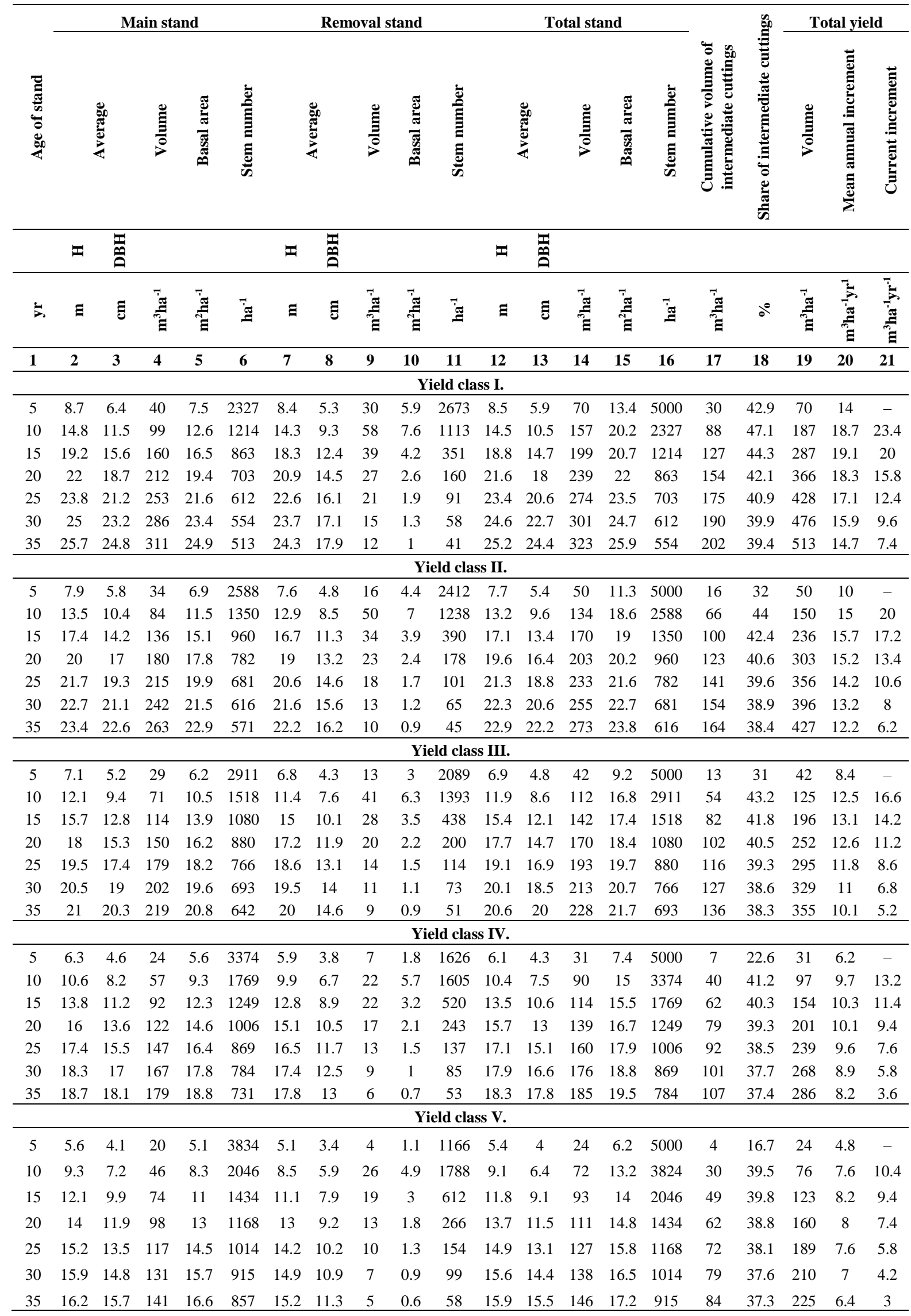


Figure $3 a-e$. Data of stand structure and yield of black locust cultivars' stands as a function of the age

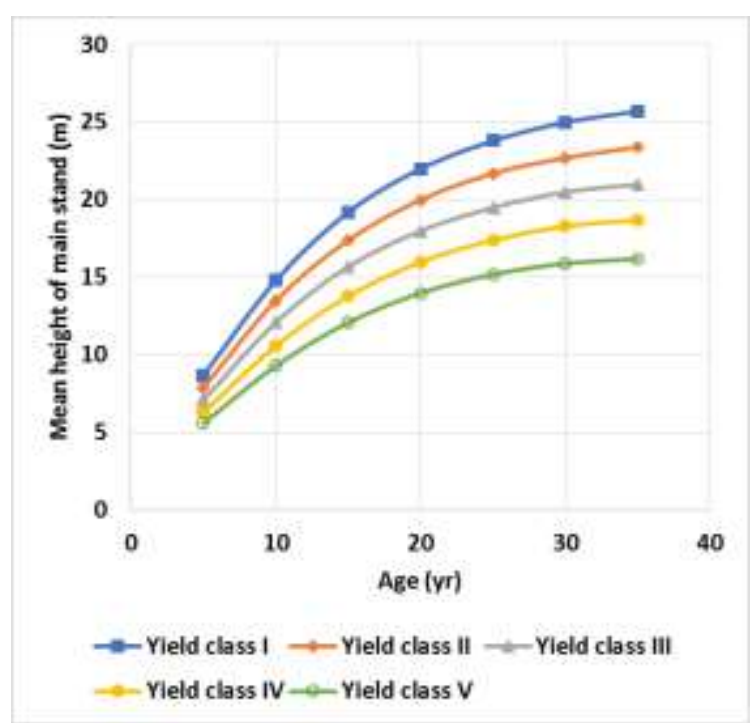

a) Mean height of the main stand, plotted against the age

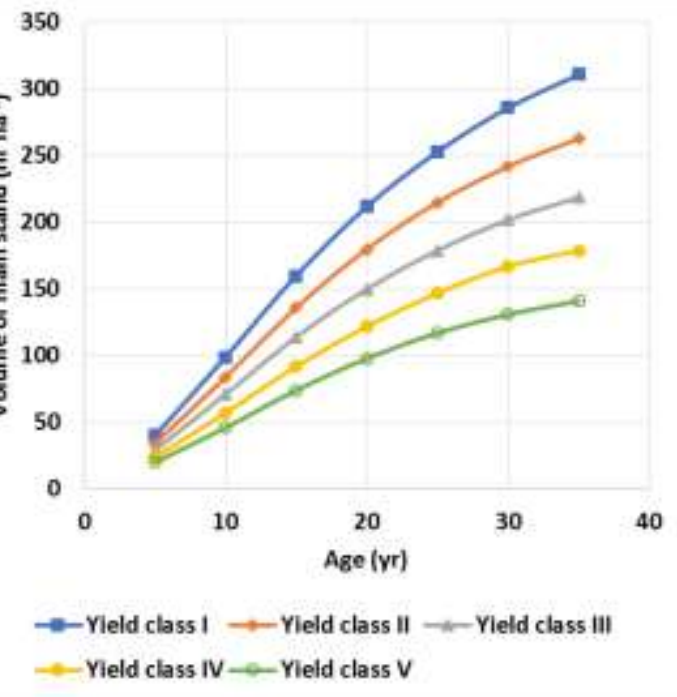

c) Volume of the main stand, plotted against the age

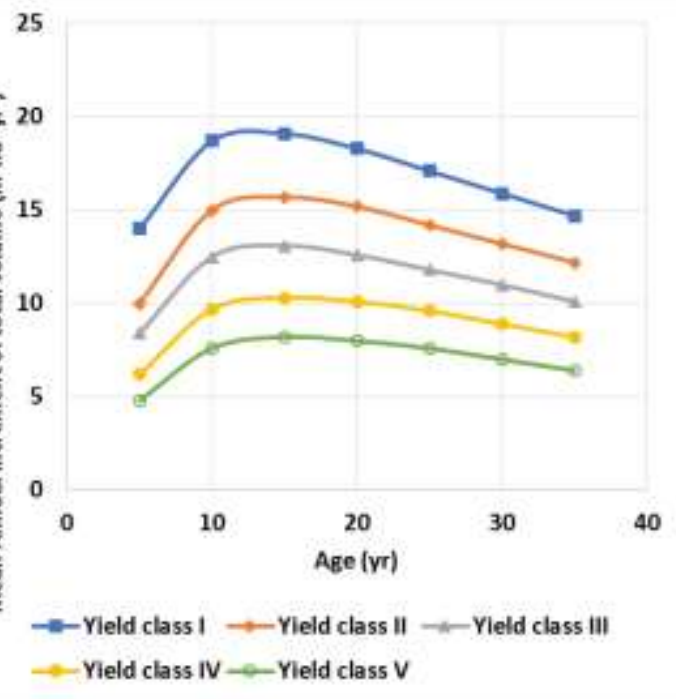

e) Mean annual increment of the total volume, plotted against the age

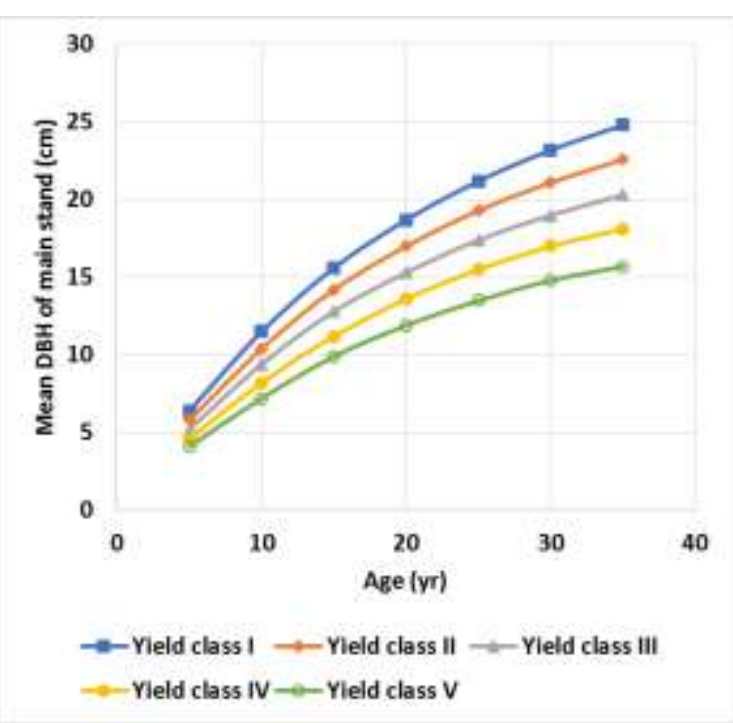

b) Mean diameter of the main stand, plotted against the age

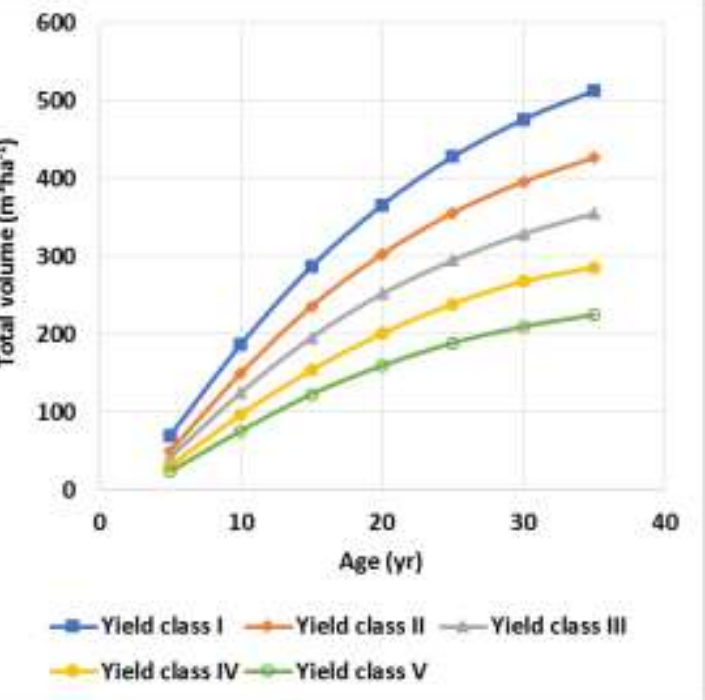

d) Total volume, plotted against the age

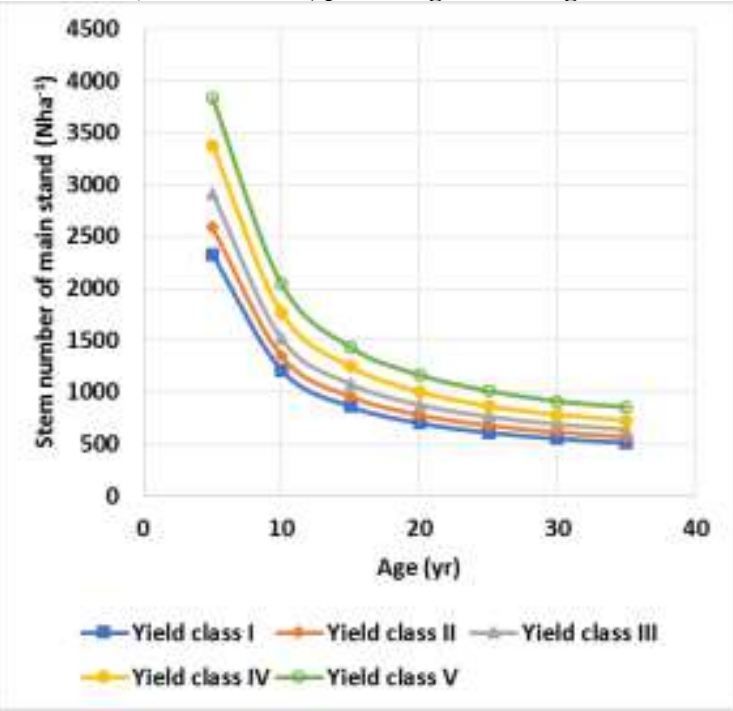

f) Stem number of the main stand, plotted against the age 


\section{CONCLUSIONS}

The yield table demonstrated in this paper supposedly applies to average rather than full stocking. In other words, an empirical yield table applies only to the average density levels found on the sample plots used. In the last decades, growth models focused on stand level data have gradually been replaced by stand growth models that predict stem number frequencies and individual-tree growth models. In spite of this fact yield tables will remain very useful tools for forest management and forest inventory in the future.

The published yield table can be widely utilized in the following fields of the Hungarian black locust cultivars' management,
- appraisal of statistical nature of the black locust cultivars' plantations and stands,

- harvest scheduling of black locust cultivars' stands, implementing the volume estimations,

- elaborating or further developing silvicultural (tending operation) models for black locust cultivars' stands.

Due to the characteristics of the experiments, the above presented results in connection with the research on the yield, stand structure and tending operations of improved black locust cultivars are preliminary investigations. Thus, the reported yield model and tending guidelines need further improving and care should be taken in applying them.

\section{REFERENCES}

Avery, T.E.-Burkhart, H.E. (1994): Forest Measurements, $5^{\text {th }}$ ed.; McGraw-Hill Education, New York, p. 480.

Bujtás, Z. (1984): The evaluation of the experiments of ship-mast formed black locust at Gödöllö. Az Erdő.33. (119.), 4, 164-165. (in Hungarian)

Demené, J.M.-Merzeau, D. (2007): Black locust. History and biological characteristics. Forêt-entreprise, 177, 10-12. (in French)

Hegede, I. (2018): Analysis of Black Locust Cultivar Comparison Experiments at Helvécia Research Station of Nation Food Chain Safety Office. Thesis (MSc). University of Sopron. Sopron. 2804-2018. p. 103. (In Hungarian)

Husch, B.-Miller, C.I.-Beers, T.W. (1982): Forest Mensuration, $4^{\text {th }}$ ed.; Wiley, New York, p. 456.

Keresztesi B. (1988): The Black Locust. Akadémia Kiadó, Budapest. p. 196.

Laar, A.-Akca, A. (2007): Forest Mensuration, $2^{\text {nd }}$ ed.; Springer Netherlands, Berlin, p. 385.

Nicolescu, V.N.-Hernea, C.-Bakti, B.-Keserü, Zs.-Antal, B.-Rédei, K. (2018): Black locust (Robinia pseudoacacia L.) as a multipurpose tree species in Hungary and Romania: a review. Journal of Forestry Research,29, 1449-1463. https://doi.org/10.1007/s11676-018-0626-5

Rédei, K. (1984): The examination of the stand structure of common and ship-mast formed black locust stands. Az Erdő, 33. (119.) 4, 166-169. (in Hungarian)
Rédei, K. (1994): Evaluation of the cultivation test of black locust cultivars. Erdészeti Lapok.129,12, 358-360. (in Hungarian)

Rédei, K. (2006): The biological basics and practice of growingimprovement of black locust. Agroinform Kiadó, Budapest. p. 128. (in Hungarian)

Rédei, K. (2008): Growing technology of selected black locust cultivars. FRI, Budapest. p. 37. (in Hungarian)

Rédei, K. (2013): Black locust (Robinia pseudoacacia L.) growing in Hungary. Agroinform Kft, Budapest. p. 77.

Rédei, K.-Csiha, I.-Keserü, Zs. (2011): Black locust (Robinia pseudoacacia L.) short-rotation crops under marginal site conditions. Acta Silvatica and Lignaria Hungarica, 7, 125-132.

Rédei, K.-Csiha, I.-Rásó, J.-Keserü, Zs. (2017): Selection of promising black locust (Robinia pseudoacacia L.) cultivars in Hungary. Journal of Forest Science, 63, 339-343. https://doi.org/10.17221/23/2017-JFS

Rédei, K.-Keserü, Zs.-Bach, I.-Rásó, J.-Ábri, T.-Szabó, F.-Gál, J. (2020): Management of Robinia pseudoacacia cv. 'Üllői' 'Üllöi' locust. Acta Silvcatica et Lignaria Hungarica, 16, 9-18.

Röhle, H. (1999): Datenbankgestützte Modellierung von Bestandeshöhenkurven. Centralblatt für das gesamte Forstwesen, 116, 35-46.

Sopp, L.-Kolozs, L. (2000): Volume tables. Forest Service, Budapest, Hungary. pp. 58-66. (in Hungarian). 